\title{
Chemical characterization of the essential oils from leaves of mandarins Sunki, Cleopatra and their hybrids
}

Josiana Z. Santos, Lucas A.H. Almeida, Walter S. Soares Filho, Humberto R. Bizzo, Marcelly Cristina da Silva Santos, Jean K.A. Mattos, Joseane P. Silva \& Roberto F. Vieira

To cite this article: Josiana Z. Santos, Lucas A.H. Almeida, Walter S. Soares Filho, Humberto R. Bizzo, Marcelly Cristina da Silva Santos, Jean K.A. Mattos, Joseane P. Silva \& Roberto F. Vieira (2015) Chemical characterization of the essential oils from leaves of mandarins Sunki, Cleopatra and their hybrids, Journal of Essential Oil Research, 27:1, 1-8, DOI: 10.1080/10412905.2014.973067

To link to this article: https://doi.org/10.1080/10412905.2014.973067

曲 Published online: 07 Nov 2014.

Submit your article to this journal $₫$

山 Article views: 216

View Crossmark data $\subset$ 


\title{
RESEARCH ARTICLE
}

\section{Chemical characterization of the essential oils from leaves of mandarins Sunki, Cleopatra and their hybrids}

\author{
Josiana Z. Santos ${ }^{a}$, Lucas A.H. Almeida ${ }^{b}$, Walter S. Soares Filho ${ }^{c}$, Humberto R. Bizzo ${ }^{\text {, }}$, Marcelly Cristina da Silva \\ Santos $^{\mathrm{d}}$, Jean K.A. Mattos ${ }^{\mathrm{a}}$, Joseane P. Silva ${ }^{\mathrm{e}}$ and Roberto F. Vieira ${ }^{\mathrm{e} *}$ \\ ${ }^{a}$ Universidade de Brasília, Brasília, Brazil; ${ }^{b}$ Universidade Federal do Recôncavo da Bahia, Cruz das Almas, Brazil; ${ }^{c}$ Embrapa \\ Mandioca e Fruticultura, Cruz das Almas, Brazil; ${ }^{d}$ Embrapa Agroindustria de Alimentos, Rio de Janeiro, Brazil; ${ }^{e}$ Embrapa \\ Recursos Genéticos e Biotecnologia, Brasília, Brazil
}

(Received 23 July 2013; accepted 30 September 2014)

\begin{abstract}
Sunki Mandarin [Citrus sunki (Hayata) hort. ex Tanaka] is a type of micromandarin from South China largely used as a rootstock in Brazil. Cleopatra mandarin (Citrus reshni hort. ex. Tanaka) is a well-formed tree, ornamental, with red-orange fruits. The main objective of this work was to analyze the chemical composition of the essential oil in leaves of accessions of Sunki and Cleopatra mandarins and hybrids. The essential oils were obtained from the leaves by hydrodistillation in a Clevenger-type apparatus and analyzed by gas chromatography/flame ionization detector (GC/FID) and GC/mass spectrometry (GC/MS). The oil yields ranged from 1.27\% (BCG562 - Hybrid of 'Sunki' C12080) to $0.33 \%$ (BCG564 - Sunki from Florida) (dry weight basis), and fifty-five constituents were detected. The major constituents were $\beta$-pinene $(2.5-49.9 \%)$, limonene $(0-49.0 \%)$, sabinene $(0.5-35.2 \%)$, linalool $(0.7-27.3 \%)$, thymol methyl ether $(0-22.3 \%)$, p-cymene $(0.2-21.2 \%), \gamma$-terpinene $(0-15.1 \%), 1.8$-cineole $(0-11.0 \%)$, terpinen-4-ol $(0.5-9.4 \%),(E)-\beta$-ocimene $(0.6-6.4 \%), \alpha$-pinene $(1.1-4.4 \%),(E)$-nerolidol $(1.0-3.2 \%)$, $\alpha$-terpineol $(0.4-3.0 \%)$ and myrcene $(0.7-2.4 \%)$.
\end{abstract}

Keywords: Citrus sunki; Citrus reshni; genetic resources

\section{Introduction}

The term micromandarin refers to the plants with small leaves, flowers and specially fruits, being apparently a homogenous group $(1,2)$. The Cleopatra (Citrus reshni hort. ex Tanaka) and Sunki [C. sunki (Hayata) hort. ex Tanaka] mandarins are well known in Brazil, both being indicated as rootstocks for oranges, tangerines and grapefruits, on light or heavy soils (3).

Sunki mandarin is a type of micromandarin from South China used as a rootstock in Brazil. It induces vigorous plants, and has precocious production when compared with the Cleopatra mandarin. Plants on this rootstock produce high-quality fruits similar to those obtained with Cleopatra mandarin, ripening by May and June. The Sunki mandarin is ornamental, resistant to scab, and tolerant to decline, saline and dry soils. It is also indicated as a female parental in citrus breeding programs via hybridization, due to the high fruit set, low polyembryony and high frequency of hybrids. Since the beginning of the last century, it has been used as a rootstock in the state of São Paulo, the largest Brazilian citrus state producer (4-7) mainly due to its compatibility with the major cultivated sweet orange, 'Pera' [C. sinensis (L.) Osbeck]. Currently, there is an increase in demand for Sunki mandarin aiming for diversifying rootstocks in the formation of new orchards (8).

The Cleopatra mandarin is an attractive tree, symmetrical and well formed, without spines, and with small dark green leaves. The fruit is orange-red, small, oblate and highly depressed at the apex, with thin and rough skin. The texture of the flesh is soft and juicy, and the flavor is slightly acidic but of great quality. It is considered native to India, and it is supposed to have been introduced in Florida just before 1888. It is an attractive ornamental species and fruits all year round (9). The Cleopatra mandarin has also been used as a rootstock in the state of São Paulo, Brazil, for almost 30 years. Varieties grafted on this plant develop rapidly, and are large and uniform. The initial production is slow and it takes two years to reach similar levels of Rangpur lime ( $C$. limonia Osbeck) and other rootstocks. However, the Cleopatra mandarin is suitable for clay soils and is highly resistant to cold. It shows late ripening of fruits, and the fruits tend to be smaller than those obtained with other rootstocks, with a nice flavor and taste. The root system is deeper (7).

Essential oils of Citrus species represent the majority of the natural flavors and fragrances industry, due to the high genetic diversity of this group of plants.

*Corresponding author. Email: roberto.vieira@embrapa.br 
Among the types of citrus essential oils marketed, those of the sweet orange (C. sinensis), mandarin (several species), true lemon [C. limon (L.) Burm. f.], sweet limes ( $C$. limettioides Tanaka, $C$. limetta Risso) and acidic lime [C. aurantiifolia (Christm.) Swingle], willow leaf mandarin (C. deliciosa Ten.) and pummelo [ $C$. maxima (Burm.) Merr.] can be highlighted.

These Citrus essential oils have been the most popular sources of perfume and fragrance essences, due to their pleasant and refreshing aroma, and the capacity to grow in extensive areas of the world. Besides the diversity among species, there is a variety of compounds and uses of citrus essential oil. They have numerous compounds and odor properties, as well as deodorizing, antimicrobial and antihypertensive activities. They are also antioxidants, helping in the prevention of diseases associated with oxidative damage (10). Among the compounds usually present in citrus essential oils, limonene, sabinene and $\beta$-pinene should be specifically mentioned. Citrus essential oils can be extracted from the peel of the fruits by cold pressing (cold-pressed oils) or by distillation (distilled lime oils), flowers (neroli), leaves and fruitlets (petitgrain) (11).

There is very little information on the chemical composition of essential oils in citrus leaves, since the vast majority of recent studies refers to essential oils from the fruit peel. Furthermore, plant material from many Citrus species is of industrial interest in the fields of pharmaceuticals, agricultural, cosmetics and food industries. The aim of this study was to analyze the chemical composition of the leaf essential oils of accessions of Sunki and Cleopatra mandarins and hybrids.

\section{Experimental \\ Plant material}

Accessions of Sunki and Cleopatra mandarins and hybrids (Table 1) were grown and harvested in the Active Germplasm Bank of Citrus (Citrus-AGB) located at Embrapa Mandioca e Fruticultura in the town of Cruz das Almas, Bahia state, at $12^{\circ} 40^{\prime} 19^{\prime}$ S $\mathrm{S}$ and 39॰ 06' 22" W.Gr., between September and November 2011. Plants were multiplied by grafting resulting in clones, grown under the same climatic conditions and similar agricultural practices. The average annual temperature is $24.1^{\circ} \mathrm{C}(12)$.

\section{Extraction of essential oil}

Mature and healthy leaves were collected from all quarters of the crown of two plants per accession. The samples were placed in paper bags, taken to a circulating air oven for four days at $38^{\circ} \mathrm{C}$ and dried to a constant weight. Dried leaves $(70 \mathrm{~g})$ of each sample were extracted by hydrodistillation in a 2-L flask for 2 hours. The essential oil was dried with anhydrous sodium sulfate, stored in amber glass sealed containers and kept refrigerated at $+5^{\circ} \mathrm{C}$.

The yield of essential oils was expressed as a percentage ( $\mathrm{g} \mathrm{EO} / 100 \mathrm{~g}$ of dried plant material), calculated

Table 1. Accessions of mandarine, denomination, origin and essential oil percentage in leaves harvested at the Citros Germplasm Bank from Embrapa Mandioca e Fruticultura, Brazil.

\begin{tabular}{|c|c|c|c|c|}
\hline $\begin{array}{l}\text { Scientific } \\
\text { name }^{\mathrm{a}}\end{array}$ & Accessions & Denomination $^{\mathrm{b}}$ & Origin & $\begin{array}{l}\%(w / w) \\
\text { Essential } \\
\text { oil }\end{array}$ \\
\hline \multicolumn{5}{|c|}{ Citrus sunki (Hayata) hort. ex Tanaka } \\
\hline & BGC562 & Hybrid of 'Sunki' C12080 & University of California, Riverside, USA & 1.27 \\
\hline & BGC563 & 'Sunki' common & Centro de Citricultura Sylvio Moreira, SP, Brazil & 0.37 \\
\hline & BGC564 & 'Sunki of Flórida' & $\begin{array}{l}\text { Faculdade de Ciências Agrárias e Veterinárias, } \\
\text { Jaboticabal, Brazil }\end{array}$ & 0.33 \\
\hline & BGC565 & 'Sunki Maravilha' & Embrapa Mandioca e Fruticultura, Brazil & 0.48 \\
\hline & BGC566 & 'Sunki Maravilha Clone 02' & Embrapa Mandioca e Fruticultura, Brazil & 0.79 \\
\hline & BGC567 & 'Sunki Tropical' & Embrapa Mandioca e Fruticultura, Brazil & 0.39 \\
\hline \multicolumn{5}{|c|}{ Citrus sunki $\times$ Citrus macrophylla Wester } \\
\hline & BGC568 & 'Sunki' $\times$ 'Alemow' & Texas, EUA & 0.43 \\
\hline \multicolumn{5}{|c|}{ Citrus reshni hort. ex Tanaka } \\
\hline & $\begin{array}{l}\text { BGC } \\
188 / 189\end{array}$ & 'Cleópatra'c & & 0.86 \\
\hline \multicolumn{5}{|c|}{ Citrus reshni $\times$ Citrus reticulata Blanco } \\
\hline & BGC192 & $\begin{array}{l}\text { Hybrid 'Cleópatra' × 'Cravo' } \\
(C \text {. limonia Osbeck })\end{array}$ & $\begin{array}{l}\text { United States Department of Agriculture, } \\
\text { California, USA }\end{array}$ & 0.35 \\
\hline
\end{tabular}

Notes: ${ }^{a}$ Scientific name based on GRIN (20). ${ }^{b}$ Denomination as cited by Passos et al. (21). ${ }^{\mathrm{c}}$ Origin not available. 
using the formula: YEO $(\%)=$ WEO $(\mathrm{g}) \times 100 / \mathrm{WDL}$ $(\mathrm{g})$, where WEO is the weight of oil extracted and WDL the weight of dry leaves used in the extraction. The amount of each compound per $\mathrm{kg}$ of dried leaves was estimated according to the formula $\mathrm{YC}$ ( $\mathrm{g} / \mathrm{kg}$ leaf) $=(\mathrm{YEO} \times C \times 0.1)$, where $\mathrm{YC}$ is the yield in grams of each compound per $\mathrm{kg}$ of dry leaves and $C$ is the relative percentage of each chemical compound (Table 2).

\section{Analysis of the essential oil}

The essential oil was diluted in dichloromethane in a proportion of $1 \%$, and then $1.0 \mu \mathrm{L}$ of the solution was injected (split 1:20) into an Agilent 7890A gas chromatograph equipped with a flame ionization detector (GC/FID) and a HP-5MS (5\% phenyl-95\% methylpolysiloxane) fused silica capillary column $(30 \mathrm{~m} \times$ $0.25 \mathrm{~mm} \times 0.25 \mu \mathrm{m}$ ). Hydrogen was used as carrier gas at a flow rate of $1.0 \mathrm{~mL} /$ minute. The oven temperature was programmed from 60 to $240^{\circ} \mathrm{C}$ at $3^{\circ} \mathrm{C} /$ minute. The injector temperature was kept at $250^{\circ} \mathrm{C}$ and the detector temperature at $280^{\circ} \mathrm{C}$. The percentage composition was obtained by area normalization. The procedure was performed in triplicate.

Analyses by GC/MS were performed on an Agilent 5973N mass selective detector coupled to an Agilent 6890 gas chromatograph fitted with a HP-5MS fused silica capillary column $(30 \mathrm{~m} \times 0.25 \mathrm{~mm} \times 0.25 \mu \mathrm{m})$. Helium was used as carrier gas at $1.0 \mathrm{~mL} /$ minute. The mass detector was operated in electronic ionization mode $(70 \mathrm{eV})$, at $3.15 \mathrm{scans} / \mathrm{second}$, with mass range from 40 to $450 \mathrm{u}$. The transfer line was kept at $260^{\circ} \mathrm{C}$, the ion source at $230^{\circ} \mathrm{C}$ and the analyzer at $150^{\circ} \mathrm{C}$. The oven temperature program and injection procedure were the same as above.

Identification of the essential oil components was performed by comparison of their mass spectra with those from the Wiley Registry of Mass Spectral Data (1994) or the NIST databases (2012), as well as their linear retention indices (LRI), after the injection of a homologous series of hydrocarbons $\left(\mathrm{C}_{7}-\mathrm{C}_{26}\right)$, in the same conditions as above, and compared with literature data $(13,14)$.

\section{Statistical analysis}

From the sum of each constituent of all samples, those with values greater than ten were considered for principal component analysis (PCA) using the method of factorization HJ-symmetric (15) in order to measure the inter-relationship among the accessions and constituents. The $\mathrm{R}$ program, public domain, was used to develop the statistical analyses (16).

\section{Results and discussion}

The accessions showed that the essential oil yield ranged from 1.27\% (BCG562 - hybrid of Sunki C12080) to $0.33 \%$ (BCG564 - Sunki from Florida). The high value of BCG 562 essential oil yield compared with the other C. sunki accessions can be probably due to their genetic differences, since they have been obtained from clones in a similar condition at the germplasm bank. On the other hand, the accession BCG192, which is a hybrid of C. reshni and Citrus reticulata, had one of the lowest values, showing no effect in essential oil yield.

Also, the levels of essential oil found in accessions BGC 188/189 (Cleopatra) with $0.86 \%$ and BGC 566 (Sunki Maravilha Clone 2) with $0.79 \%$ (Table 1) can be highlighted. The essential oil yield reported in the literature for different genotypes of citrus, extracted by steam distillation of fresh leaves, ranged between $0.05 \%$ and $0.60 \%(17,18)$. Although they should not be compared, as they have been extracted in different processes, the essential oil yields obtained at CitrusABG showed a reasonable content.

Among the accessions, BGC192 (a hybrid of Cleopatra mandarin with Rangpur lime) showed the highest percentage of total identification of the essential oil (98.7\%), distributed in thirty-two constituents, followed by accession BGC567 (Sunki tropical mandarin) with $87.3 \%$ of essential oil components identified divided into thirty-eight constituents. Sabinene was the major compound in both accessions, with $30.5 \%$ and $31.5 \%$, respectively.

Table 2 presents the percentages of the chemical constituents of the essential oil of each accession studied. A total of fifty-five components were identified, ranging from $87.3 \%$ to $98.7 \%$ of the constituents detected. The main constituents were: $\beta$-pinene $(0-$ $49.9 \%)$, limonene $(0-49.0 \%)$, sabinene $(0.5-35.2 \%)$, linalool (0.7-27.3\%), thymol methyl ether (0-22.3\%) p-cymene $(0.2-21.2 \%), \gamma$-terpinene $(0-15.1 \%), 1,8$-cineole $(0-10.9 \%)$, terpinen-4-ol $(0.5-9.4 \%),(E)-\beta$-ocimene $(0.6-6.4 \%), \alpha$-pinene $(1.1-4.4 \%), \quad(E)$-nerolidol (1.0-3.2\%), $\alpha$-terpineol (0.4-3.0\%) and myrcene (0.7$2.4 \%$ ) (Figure 1).

The major compounds of each accession evidence a large variation of the Citrus-ACG mandarin collection. Among the C. sunki accessions, a high level of $\beta$ pinene was observed in BCG 563 and $564(45.5 \%$ and 49.9\%), and also in BCG 565 and 566 - these last two with the presence high values of p-cymene and $\gamma$-terpinene. BCG 562, which is a hybrid, showed a different profile, with a predominance of thymol methyl ether (22.3\%), p-cymene and $\gamma$-terpinene. BCG 567 also showed a distinct profile, with high values of sabinene $(31.5 \%)$, similar to the C. reshni accessions. 
Table 2. Relative percentage of essential oil constituents of leaves from accessions of Citrus sunki, Citrus reshni and hybrids from Embrapa Citros Germplasm Bank, Brazil.

\begin{tabular}{|c|c|c|c|c|c|c|c|c|c|c|c|}
\hline \multirow[b]{2}{*}{ Peak } & \multirow[b]{2}{*}{ Constituents } & \multirow[b]{2}{*}{$\mathrm{LRI}^{\mathrm{a}}$} & \multicolumn{9}{|c|}{ Accessions $^{\mathrm{b}}$} \\
\hline & & & $\begin{array}{c}\text { BGC } \\
562\end{array}$ & $\begin{array}{c}\text { BGC } \\
563\end{array}$ & $\begin{array}{c}\text { BGC } \\
564\end{array}$ & $\begin{array}{c}\text { BGC } \\
565\end{array}$ & $\begin{array}{c}\text { BGC } \\
566\end{array}$ & $\begin{array}{c}\text { BGC } \\
567\end{array}$ & $\begin{array}{c}\text { BGC } \\
568\end{array}$ & $\begin{array}{c}\text { BGC } \\
192\end{array}$ & $\begin{array}{c}\text { BGC } \\
188 / 189\end{array}$ \\
\hline 1 & $\alpha$-Thujene & 926 & 1.9 & 0.4 & 0.3 & 1.3 & 1.3 & 0.9 & 0.1 & 0.4 & 0.6 \\
\hline 2 & $\alpha$-Pinene & 933 & 4.3 & 3.2 & 4.1 & 4.3 & 4.4 & 2.4 & 1.1 & 1.8 & 1.5 \\
\hline 3 & Camphene & 948 & & 0.2 & 0.3 & 0.1 & 0.1 & 0.1 & 0.1 & & \\
\hline 4 & Sabinene & 974 & 0.5 & 8.9 & 9.5 & 5.6 & 5.1 & 31.5 & 2.5 & 30.5 & 35.2 \\
\hline 5 & $\beta$-Pinene & 977 & 4.6 & 45.5 & 49.9 & 25.3 & 24.1 & 9.4 & 16.0 & 8.5 & 2.5 \\
\hline 6 & 6-Methyl-5-hepten-2-one & 988 & & & & & & & 0.9 & & \\
\hline 7 & Myrcene & 991 & 1.2 & 0.7 & 0.8 & 1.0 & 1.1 & 2.4 & 1.2 & 2.2 & 2.4 \\
\hline 8 & $\alpha$-Phellandrene & 1006 & 0.1 & 0.2 & & & & 0.3 & & 0.1 & 0.1 \\
\hline 9 & $\delta$-3-Carene & 1011 & & 0.2 & & & & 0.2 & & & \\
\hline 10 & $\alpha$-Terpinene & 1017 & 0.3 & 0.1 & & 0.2 & 0.2 & 0.7 & & 0.6 & 1.4 \\
\hline 11 & $p$-Cymene & 1025 & 15.0 & 0.8 & 0.9 & 21.2 & 20.8 & 2.7 & 0.2 & 0.7 & 0.7 \\
\hline 12 & Limonene & 1028 & 3.6 & 1.9 & 2.2 & 3.1 & 3.3 & 1.6 & 49.0 & 24.9 & \\
\hline 13 & 1,8-Cineole & 1031 & 0.2 & 10.9 & 4.7 & 7.8 & 6.3 & 0.2 & & 0.4 & \\
\hline 14 & $(Z)-\beta$-Ocimene & 1037 & 0.3 & 0.3 & 0.1 & 0.2 & 0.2 & 0.3 & 0.1 & 0.2 & 0.2 \\
\hline 15 & (E)- $\beta$-Ocimene & 1047 & 6.4 & 1.7 & 1.3 & 3.4 & 4.6 & 3.3 & 0.6 & 4.9 & 4.3 \\
\hline 16 & $\gamma$-Terpinene & 1058 & 14.0 & 0.3 & 0.1 & 12.7 & 15.1 & 1.4 & & 1.3 & 2.7 \\
\hline 17 & cis-Sabinene hydrate & 1070 & 0.1 & 0.5 & 0.6 & 0.6 & 0.5 & 2.2 & 0.1 & 1.0 & 1.4 \\
\hline 18 & cis-Linalool oxide & 1074 & 0.2 & & & 0.1 & 0.1 & 0.2 & 0.2 & & 0.1 \\
\hline 19 & Terpinolene & 1089 & 2.8 & 0.2 & 0.1 & 0.8 & 0.9 & 0.5 & 0.1 & 0.4 & 0.8 \\
\hline 20 & trans-Linalool oxide & 1091 & & & & & & & 0.1 & & \\
\hline 21 & Linalool & 1106 & 12.3 & 1.0 & 1.0 & 0.8 & 0.7 & 5.7 & 1.2 & 1.8 & 27.3 \\
\hline 22 & cis-p-2-Menthen-1-ol & 1125 & 0.1 & 0.3 & 0.1 & 0.2 & 0.2 & 0.8 & 0.2 & 0.3 & 0.6 \\
\hline 23 & cis-Limonene oxide & 1134 & 0.2 & 0.3 & 0.4 & 0.2 & 0.2 & 0.5 & 0.3 & 0.2 & 0.3 \\
\hline 24 & trans-Limonene oxide & 1139 & 0.3 & & & 0.2 & 0.3 & & & & \\
\hline 25 & Nopinone & 1140 & & 0.2 & 1.2 & & & & 0.2 & & 0.5 \\
\hline 26 & trans-Pinocarveol & 1144 & & 0.4 & 1.2 & & 0.1 & 0.4 & & 0.5 & \\
\hline 27 & Citronellal & 1155 & & & & & & & 1.5 & 0.3 & \\
\hline 28 & Sabinone & 1165 & & & & & 0.2 & & 0.2 & & \\
\hline 29 & Terpinen-4-ol & 1181 & 0.5 & 1.9 & 1.4 & 1.4 & 1.2 & 9.2 & 0.6 & 5.1 & 9.4 \\
\hline 30 & $\alpha$-Terpineol & 1197 & 0.4 & 3.0 & 1.3 & 1.5 & 1.1 & 1.3 & 0.6 & 0.9 & 1.0 \\
\hline 31 & Myrtenol & 1199 & 0.1 & 0.4 & 0.4 & 0.2 & 0.2 & 0.4 & 0.2 & & \\
\hline 32 & Thymol methyl ether & 1237 & 22.3 & & 0.1 & & & & & & \\
\hline 33 & Nerol & 1244 & & & 0.2 & & & & 2.3 & 0.2 & 0.1 \\
\hline 34 & Neral & 1247 & & & & & & 0.3 & 3.4 & 2.0 & \\
\hline 35 & Geraniol & 1256 & 0.1 & & & & 0.1 & 0.2 & 1.0 & 1.3 & \\
\hline 36 & Geranial & 1274 & 4.3 & & & & & & 3.0 & 0.7 & \\
\hline 37 & $\alpha$-Cubebene & 1337 & & & 0.2 & & 0.1 & & & & 0.2 \\
\hline 38 & Citronellyl acetate & 1356 & & & & & & & 0.3 & & \\
\hline 39 & Neryl acetate & 1367 & & & & & & & 1.5 & 0.3 & \\
\hline 40 & Geranyl acetate & 1387 & & 0.1 & & & 0.2 & 0.2 & 1.0 & 2.1 & \\
\hline 41 & $\beta$-Elemene & 1392 & & 0.4 & 0.7 & 0.1 & 0.2 & 0.4 & 0.2 & & 0.1 \\
\hline 42 & (E)- $\beta$-Caryophyllene & 1418 & 0.1 & 0.6 & 0.8 & 0.5 & 0.4 & 1.0 & 0.6 & 2.9 & 0.4 \\
\hline 43 & $\alpha$-Humulene & 1453 & & 0.2 & 0.4 & 0.2 & 0.1 & 0.3 & 0.2 & 0.3 & 0.1 \\
\hline 44 & Germacrene D & 1481 & & & & & & & & & 0.4 \\
\hline 45 & Elemol & 1549 & & 1.7 & 2.5 & 0.3 & 0.1 & 1.2 & 0.3 & & 0.6 \\
\hline 46 & Germacrene B & 1560 & 0.2 & & & & & & & & \\
\hline 47 & (E)-Nerolidol & 1569 & 1.2 & 1.3 & 3.2 & 1.8 & 1.8 & 1.8 & 2.2 & 1.0 & 0.1 \\
\hline 48 & Spathulenol & 1583 & 0.4 & 0.5 & 1.0 & 0.7 & 0.7 & 1.3 & 1.2 & 1.0 & 0.1 \\
\hline 49 & Caryophyllene oxide & 1595 & & 0.1 & & & & & & & \\
\hline 50 & Humulene epoxide II & 1608 & & 0.1 & 0.2 & 0.1 & 0.1 & 0.3 & 0.1 & & \\
\hline 51 & iso-Spathulenol & 1630 & & 0.6 & 1.2 & 0.9 & 0.4 & 0.6 & 0.2 & & \\
\hline 52 & $\alpha$-Muurolol & 1637 & & 0.9 & 1.2 & & & 0.7 & & & \\
\hline 53 & $\alpha$-Cadinol & 1648 & & 0.4 & 0.8 & 0.3 & 0.3 & 0.2 & 0.3 & & 0.1 \\
\hline 54 & $\beta$-Sinensal & 1708 & & 0.1 & 0.2 & 0.2 & 0.1 & 0.3 & 0.3 & & \\
\hline \multirow[t]{2}{*}{55} & $\alpha$-Sinensal & 1758 & & 0.1 & 0.2 & 0.2 & 0.2 & 0.2 & & & \\
\hline & Monoterpenes & & 54.8 & 54.8 & 64.5 & 69.5 & 79.2 & 81.2 & 57.5 & 71.1 & 76.5 \\
\hline
\end{tabular}


Table 2. (Continued)

\begin{tabular}{|c|c|c|c|c|c|c|c|c|c|c|c|}
\hline \multirow[b]{2}{*}{ Peak } & \multirow[b]{2}{*}{ Constituents } & \multirow[b]{2}{*}{$\mathrm{LRI}^{\mathrm{a}}$} & \multicolumn{9}{|c|}{ Accessions $^{\mathrm{b}}$} \\
\hline & & & $\begin{array}{c}\text { BGC } \\
562\end{array}$ & $\begin{array}{c}\text { BGC } \\
563\end{array}$ & $\begin{array}{c}\text { BGC } \\
564\end{array}$ & $\begin{array}{c}\text { BGC } \\
565\end{array}$ & $\begin{array}{c}\text { BGC } \\
566\end{array}$ & $\begin{array}{c}\text { BGC } \\
567\end{array}$ & $\begin{array}{c}\text { BGC } \\
568\end{array}$ & $\begin{array}{c}\text { BGC } \\
192\end{array}$ & $\begin{array}{c}\text { BGC } \\
188 / 189\end{array}$ \\
\hline & Oxygenated monoterpenes & & 41.1 & 41.1 & 19.1 & 12.6 & 12.9 & 11.3 & 21.6 & 18.8 & 16.9 \\
\hline & Sesquiterpenes & & 0.3 & 0.3 & 1.2 & 2.1 & 0.8 & 0.8 & 1.7 & 0.9 & 3.2 \\
\hline & Oxygenated sesquiterpenes & & 1.5 & 1.5 & 5.8 & 10.3 & 4.5 & 3.8 & 6.5 & 4.7 & 2.0 \\
\hline & Total & & 97.7 & 90.6 & 94.4 & 97.3 & 96.9 & 87.3 & 95.4 & 98.7 & 95.1 \\
\hline
\end{tabular}

Notes: ${ }^{\mathrm{a}}$ Linear retention indices on DB-5. ${ }^{\mathrm{b}}$ Accessions: BGC 562 (Sunki hybrid C12080), BGC 563 (common Sunki), BGC 564 (Florida Sunki), BGC 565 (Sunki Maravilha), BGC 566 (Sunki Maravilha Clone 02), BGC 567 (Sunki Tropical), BGC 568 (Sunki $\times$ Alemow), BGC 188/189 (Cleopatra) and BGC 192 (Cleopatra $\times$ Cravo Hybrid).

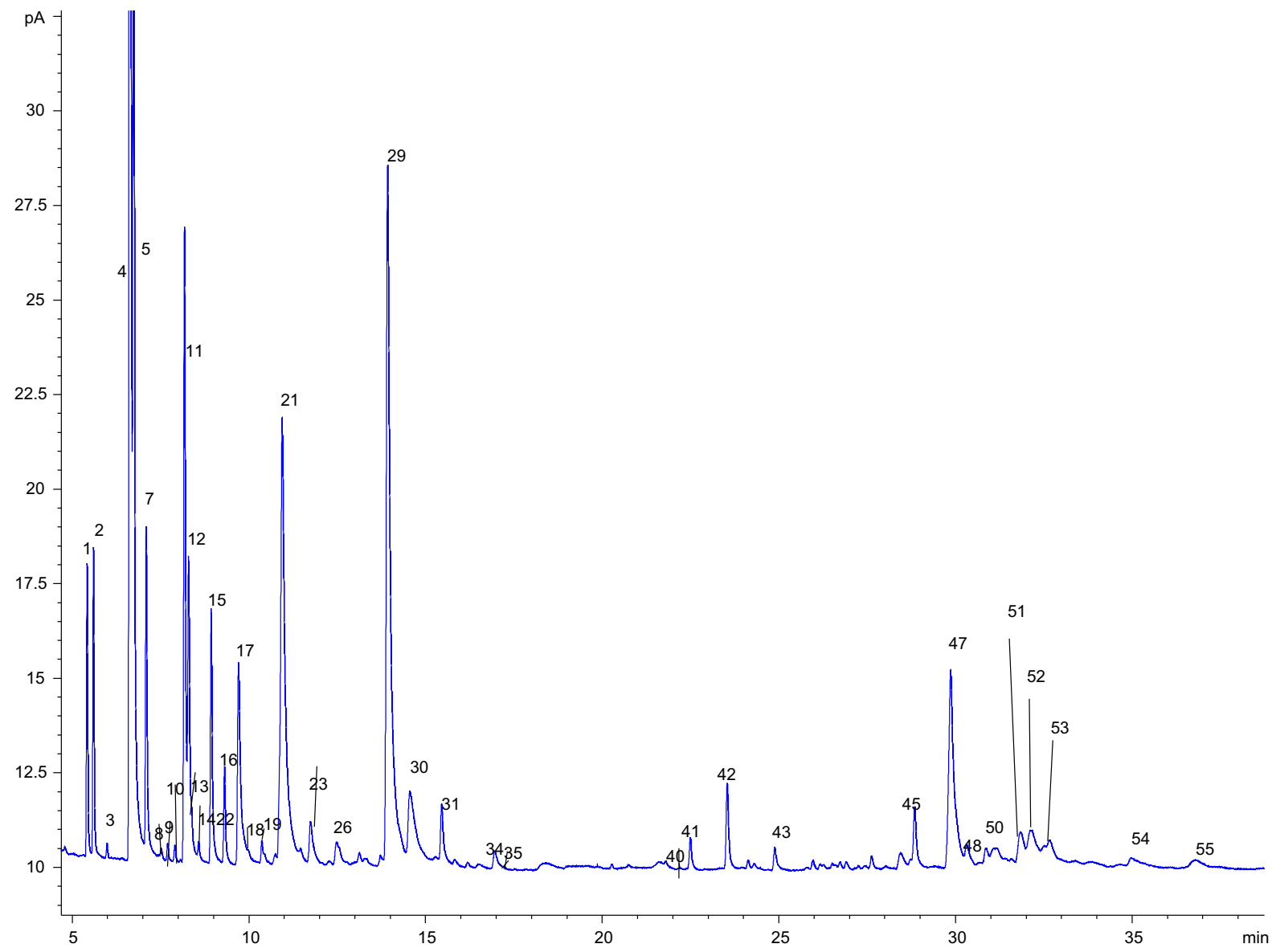

Figure 1. Chromatogram of Citrus sunki accession BGC 567 and its constituents.

In the Cleopatra accession BCG 568 and its hybrid with C. reticulata (BCG192), a high content of limonene was observed ( $49 \%$ and $24.9 \%$ ), followed by $\beta$ pinene and sabinene, respectively. The accession BCG $188 / 189$ showed the highest value for linalool (27.3\%), but also presented some levels of sabinene. It a high percentage of monoterpenes was observed in all accessions, with the predominance of oxygenated monoter- penes in the accessions of C. sunki BCG 562 and 563 (Table 2).

There are only few studies on the literature reporting the essential oil composition of $C$. sunki and C. reshni. In 2000 and 2001, Lota and collaborators $(17,18)$ have reported the composition of leaf essential oils of mandarins, including Cleopatra (C. reshni) and Sunki varieties. 
The essential oil of mandarins leaves have been reported in the literature as containing fifty-eight constituents, with sabinene $(0.1-57.3 \%), \gamma$-terpinene $(0.1-$ 67.4\%), linalool (traces-59.3\%) and methyl $N$-methylanthranylate (traces-78.7\%) as major constituents (18). The highest values obtained for sabinene $(35.2 \%), \gamma$ terpinene $(15.1 \%)$ and linalool $(27.3 \%)$ were lower than those presented in the literature, and no methyl $\mathrm{N}$ methyl-anthranylate was detected in the Citrus-ACG. Furthermore, the quantitative values obtained can be affected by the environmental conditions observed in the places where the plants were collected. However, the qualitative profiles seem quite consistent, considering that the plants analyzed were harvested at similar environmental conditions.

In the essential oil from the leaves of a variety of Cleopatra, $97.2 \%$ of the compounds were identified, and $89.6 \%$ of these were also observed in two accessions of Citros-AGB (BGC192 and BGC188/189). The compounds that were present in both studies were $\alpha$-thujene, $\alpha$-pinene, sabinene, myrcene, $(Z)-\beta$-ocimene, $(E)$ - $\beta$-ocimene, $\gamma$-terpinene, terpinolene, linalool, terpinen-4-ol, $(E)$ - $\beta$-caryophyllene and $\alpha$-humulene (18).

Similarly, in the leaf essential oil of a variety of Sunki mandarin reported in the literature (18), 90.7\% had a similar composition to the seven samples of Sunki accessions studied (BGC 562, 563, 564, 565,
566, 567 and 568), and the following compounds were presented in all samples when compared with the literature: $\alpha$-thujene, $\alpha$-pinene, sabinene, myrcene, $\mathrm{p}$-cymene, limonene, $(Z)-\beta$-ocimene, $(E)$ - $\beta$-ocimene, linalool and terpinen-4-ol (18).

The essential oil from leaves of 113 samples of various citrus genotypes reported in the literature presented almost the same number of compounds, among which the most important were: methyl $N$-methyl-anthranylate $(<0.1-85.2 \%), \quad$ linalool $\quad(<0.1-76.4 \%), \quad \gamma$-terpinene $(<0.1-63.4 \%)$, sabinene $(<0.1-57.2 \%)$, limonene $(1.7-$ $55.8 \%),(E)$ - $\beta$-ocimene $(0.1-20.6 \%)$, ethyl $N$-methyl-anthranylate $(0-16.2 \%)$, thymol $(<0.1-13.0 \%), \delta$-3-carene $(<0.1-11.1 \%)$ and citronellal $(<0.1-11.7 \%)(19)$.

Regarding the performance of the main chemical constituents of the essential oil (in grams of each constituent per kilogram of dry leaves), the following accessions can be highlighted: Cleopatra (BGC188/ 189 ), with the presence of $3.03 \mathrm{~g} / \mathrm{kg}$ of sabinene, $0.21 \mathrm{~g} / \mathrm{kg}$ of myrcene and $2.35 \mathrm{~g} / \mathrm{kg}$ of linalool; the hybrid Sunki C12080 (BGC562) with a high content of $\gamma$-terpinene $(2.8 \mathrm{~g} / \mathrm{kg})$, nerol $(2.8 \mathrm{~g} / \mathrm{kg})$ and p-cymene $(1.92 \mathrm{~g} / \mathrm{kg})$. For the compound $\beta$-pinene, accession BGC566 (Sunki Maravilha clone 2) had the highest yield of $1.91 \mathrm{~g} / \mathrm{kg}$ followed by accession BGC 568 (C. sunki $\times$ Citrus macrophylla Wester) with $2.11 \mathrm{~g} / \mathrm{kg}$.

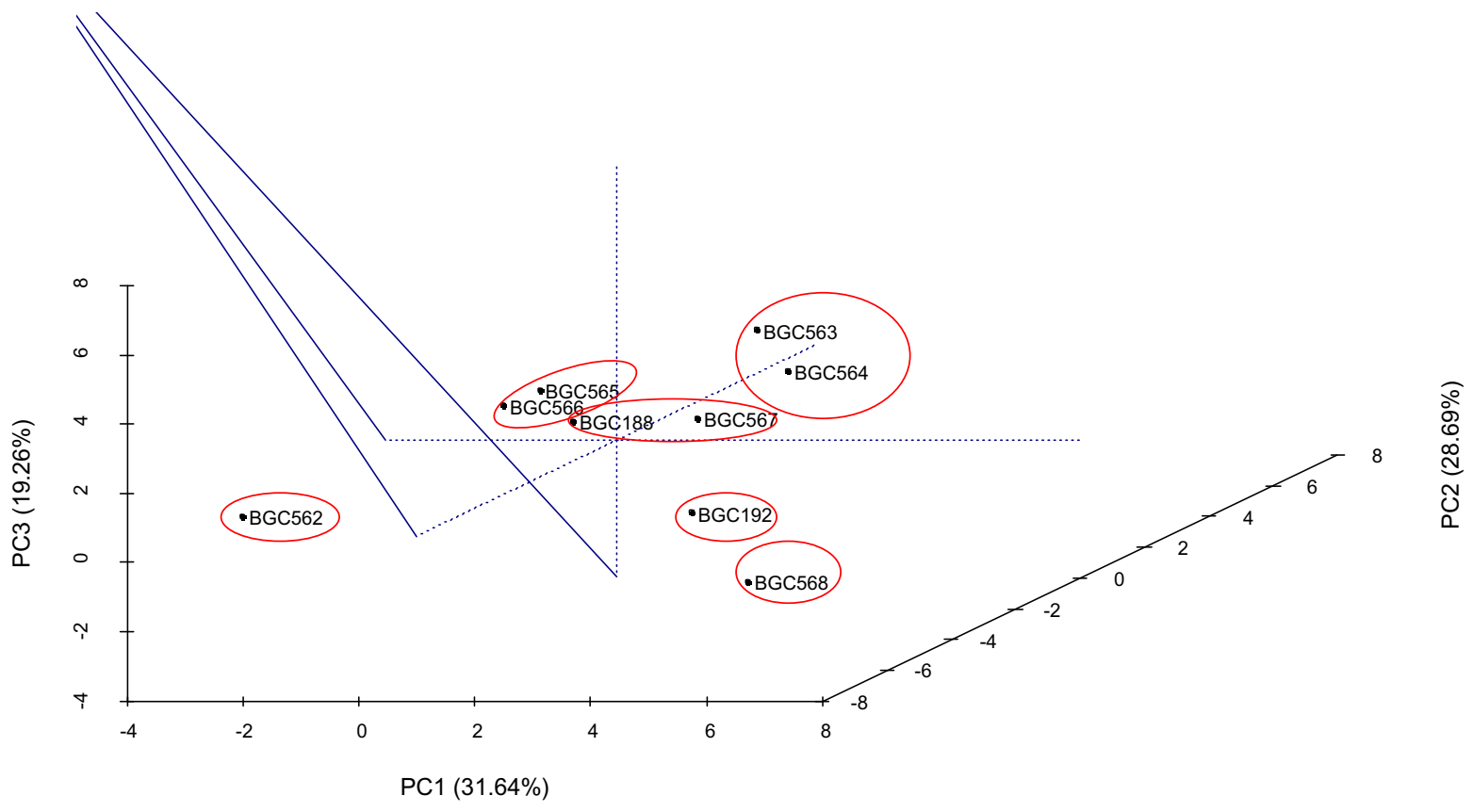

Figure 2. Principal component analysis of essential oil chemical constituents from leaves of accessions of Citrus sunki (Hayata) hort. ex Tanaka, Citrus reshni hort. ex Tanaka and hybrids from the Citros Germplasm Bank, Embrapa Mandioca e Fruticultura, Brazil. *Accessions: BGC 562 (hybrid of Sunki C12080), BGC 563 (Sunki common), BGC 564 (Sunki from Florida), BGC 565 (Sunki Maravilha), BGC 566 (Sunki Maravilha Clone 02), BGC 567 (Sunki Tropical), BGC 568 (Sunki × Alemow), BGC 188/ 189 (Cleopatra) and BGC 192 (hybrid Cleopatra $\times$ Cravo). 
PCA was based on twenty-two major constituents, with sum values above 5\% showing the highest expression to discriminate accessions. PCA allowed accession separation into three components (Figure 2). The first component (PC1) accounted for $31.64 \%$ of the existing variability, showing as major discriminant constituents terpinolene, $\alpha$-thujene, thymol methyl ether, $\alpha$-pinene, $\gamma$-terpinene and p-cymene, which separated accession BGC562 (hybrid 'Sunki' C12080) from the rest of the group. The second component (PC2) allowed an explanation of the $28.69 \%$ variation between accessions and had as major constituents myrcene, $(E)$-nerolidol, 1,8cineole, linalool and $\beta$-pinene. PC2 discriminated accession BGC188/189 (Cleopatra) from BGC563 (common Sunki mandarin) and BGC564 (Sunki from Florida mandarin). Finally, the third component (PC3) allowed an explanation of the $19.26 \%$ existing variation and had as major constituents neral, geranial and limonene, which allowed separation of BGC568 [Sunki $\times$ Alemow (C. macrophylla)] from the rest of the group.

In Figure 2, a separation of six types of chemical profiles based on PCA analysis can be observed. The first type is characterized by accession BGC562 (Sunki hybrid C12080), whose main chemical components are thymol methyl ether, terpinolene and geranial. The second type is characterized by accession BGC563 (common Sunki mandarin) and BGC564 (Sunki from Florida mandarin), with the main differential element $\beta$ pinene $(45.5 \%$ and $49.9 \%$, respectively), but with influences from elemol and $\alpha$-terpineol. The values obtained for $\beta$-pinene are quite high compared with the other accessions.

The third group is characterized by accession BGC565 (tangerine 'Sunki Maravilha') and BGC566 (Sunki Maravilha mandarin clone 2), and the main element was p-cymene, with influences of 1,8 cineole and $\beta$-pinene. $\gamma$-terpinene also influences the formation of this type, as it is present in concentrations of $12.67 \%$ and $15.14 \%$ in its constituents, two of the largest concentrations found in the samples analyzed. The fourth type is formed by BGC567 (Sunki Tropical mandarin) and BGC188/189 (Cleopatra), which differ from the other accessions by the chemical constituents cis-sabinene hydrate, myrcene, terpinen-4-ol and sabinene. They also present a consistent difference in linalool value.

Accession BGC192 (hybrid of Cleopatra mandarin with Rangpur lime) had influences of chemical compounds such as neral, (E)- $\beta$-caryophyllene and limonene, being considered the fifth type.

The sixth type consists of accession BGC568 (Sunki $\times$ Alemow) and has limonene as the major compound (49\%), and influences of spathulenol and (E)-nerolidol. The accessions BGC567, 188/189 and 192 have values close to sabinene but differ in the quantities of the other secondary constituents. In BGC568, the highest value was limonene, showing a large variation among the essential oils of citrus leaf analyzed.

In conclusion, the leaf essential oil of different accessions of C. sunki, C. reshni and hybrids showed a large variability of constituents, mostly recognized also in other citrus leaves in literature. Limonene, sabinene and $\beta$ pinene were the major constituents. The observed amount of essential oil was also variable, but some accessions have showed a yield superior to $1 \% \mathrm{w} / \mathrm{w}$. PCA was able to separate different accession groups based on essential oil composition. A further study on olfactory evaluation and its potential associated with Citrus disease resistance could be interesting to better evaluate the potential of these germplasms for industry, as this specific group of Citrus has a good agronomical feasibility.

\section{Acknowledgements}

The authors would like to thank the Citros Active Germplasm Bank team of Embrapa Mandioca e Fruticultura for the availability of the plant material. We are also grateful for the support of the University of Brasilia graduate program.

\section{References}

1. R.W. Hodgson, Horticultural varieties of citrus. In: The Citrus Industry. Edits., W. Reuther, L.D. Batchelor and H.J. Webber, volume 1, pp. 431-591, University of California, Berkley, CA (1967).

2. G.W. Müller, F.F. Laranjeira, J. Pompeu Júnior, M. Cristofani and M.F. Jorge, Epidemias de declínio dos citros em combinações com tangerina-Cleópatra como porta-enxerto no Estado de São Paulo. Fitopatol. Bras., 22, 345 (1997).

3. R.P. Leite Júnior, Cultivares de copa de porta-enxertos, In: A citricultura no Paraná. Coord., S.L.C. Carvalho, pp. 91-116, IAPAR, Londrina (1992).

4. J.E.O. Lima, Aspectos da instalação e do manejo do pomar. Laranja, Cordeirópolis, 14, 623-633 (1993).

5. J. Pompeu Júnior, Porta-enxertos. In: Citricultura brasileira, 2nd edn. Edits., O. Rodriguez, F.C.P. Viegas J. Pompeu Jr. and A.A. Amaro, volume 1, pp. 265-280, Campinas, Fundação Cargill (1991).

6. W. dos S. Soares Filho, C. dos S. Moreira, M.A.P. da Cunha, A.P. da Cunha Sobrinho and O.S. Pessoa, Poliembrionia e freqüência de híbridos em Citrus spp. Pesquisa Agropecuária Brasileira, Brasília, DF, 35, 857-864 (2000).

7. J. Pompeu Júnior, Porta-enxertos. In: D. Mattos Júnior, J.D. Negri, R.M. Pio, and J. Pompeu Júnior, Citros, pp. 63-104, FUNDAG, Campinas (2005).

8. FUNDECITRUS. Fundo de Defesa da Citricultura. http:// www.fundecitrus.com.br/ (10 February 2008).

9. CITRUSPAGES. Mandarins. Website. http://users.kymp. net/citruspages/mandarinhybrids.html\#reshni/ (27 August 2012). 
10. M. Sawamura, Introduction and overview. In: Citrus essential oils: Flavor and fragrance. Edits., M. Sawamura, pp. 1-36, Wiley, New York, NY (2010).

11. G. Dugo, A. Cotroneo and I. BanaccorsiI. Composition of petitgrain oils. In: Citrus oils: Composition, advanced analytical techniques, contaminantes, and biological activity. Edits., G. Dugo and L. Mondello, pp. 253-331, CRC Press, London (2011).

12. O.A. Almeida, Informações meteorológicas do CNP. Documentos, 34. Embrapa, Cruz das Almas (1999).

13. H. Van Den Dool and P.D.J.A. Kratz, A generalization of the retention index system including linear temperature programmed gas-liquid partition chromatography. J. Chromatogr., 2, 463-471 (1963).

14. R.P. Adams, Identification of Essential Oil Components by Gas Chromatography/ Mass Spectrometry, 4th ed. Allured Publ. Corp, Carol Stream, IL (2007).

15. M.P. Galindo, Uma alternativa de representacion simultanea: HJ-Biplot. Questiio, 101, 3-23 (1986).

16. R Core Team. A language and environment for statistical computing. R Foundation for Statistical Computing, Vienna. http://www.R-project.org/ (22 January 2012).
17. M.L. Lota, D. de R. Serra, F. Tomi and J. Casanova, Chemical variability of peel and leaf essential oils of mandarins from Citrus reticulata Blanco. Biochem. Syst. Ecol., 28, 61-78 (2000).

18. M.L. Lota, D. de R. Serra, F. Tomi and J. Casanova, Chemical variability of peel and leaf essential oils of 15 species of mandarins. Biochem. Syst. Ecol., 29, 77-104 (2001).

19. F. Tomi, M. Barzalona and J. Casanova, Chemical variability of the leaf oil of 113 hybrids from Citrus clementine (Commun) $\times$ Citrus deliciosa (Willow Leaf). Flavour Fragr. J., 23, 152-163 (2008).

20. GRIN - Germplasm Resources Information Network. CITRUS. http://www.ars-grin.gov/cgi-bin/npgs/html/ taxon.pl?10714 (13 May 2013).

21. O.S. Passos, W. dos S. Soares Filho, A.P. da C Sobrinho, A. da S. Souza, L.C. dos Santos and L.S. Peixoto, $O$ Banco ativo de germoplasma de citros da Embrapa Mandioca e Fruticultura tropical: passado, presente e futuro. Embrapa Mandioca e Fruticultura, Dados eletrônicos Cruz das Almas (2007). http://www.infoteca.cnptia.embra pa.br/handle/doc/655625 (10 May 2011). 